ISSN : 2302 - 7517, Vol. 03, No. 03

\title{
SKEMA HUTAN KEMASYARAKATAN (HKM) KOLABORATIF SEBAGAI SOLUSI PENYELESAIAN KONFLIK PENGELOLAAN SDADI HUTAN SESAOT, LOMBOK BARAT
}

\author{
Scheme of Community Forest (HKm) as a Collaborative Solution Conflict Resolution \\ Management of Natural Resources in the Forest Sesaot, West Lombok
}

\author{
Ali Yansyah Abdurrahim *) \\ Bidang Ekologi Manusia, Pusat Penelitian Kependudukan \\ Lembaga Ilmu Pengetahuan Indonesia (LIPI) \\ *)email: aliyansyah.lipi@gmail.com
}

\begin{abstract}
Forest Enactment Sesaot into regional Forest Park (TAHURA) through a ministerial decree No. 244 / KptsII / 1999 and No. 598 / Menhut-II / 2009 conflict between the various interested parties. Research with qualitative approach is wanted (1) map the problem (dynamics) access, property, power, and authority over natural resources in the Forest Sesaot before and after establishment; (2) analyze the structure and stages of the conflict and relations (collection and nets) power of the actors involved; (3) merekomendasikanskema collaborative management sebagaisolusi conflict resolution. The study found that conflict management of natural resources in the forest Sesaot sourced from struggles over access and management rights between the Government of West Nusa Tenggara with local people who then received support from the Government of West Lombok. With relationships, collection, and net power it has, the NTB provincial government support TAHURA scheme, while the West Lombok regency HKm support scheme (Community Forest). Third party managed to defuse the conflict with the decision to restore the status of forest functions Sesaot scheme TAHURA location HKm and move to other areas outside the forest area Sesaot. However, not all parties are satisfied with this decision. To avoid conflicts from happening in the future, the authors recommend a modified scheme HKm kolabaratif HKm be able to accommodate the interests of all parties.
\end{abstract}

Keywords: collaborative management, community forestry (HKm), conflict, political ecology, Sesaot forests

\begin{abstract}
ABSTRAK
DitetapkannyaHutanSesaotmenjadikawasanTamanHutanRakyat(TAHURA)melaluiSKMenteriKehutanan Nomor 244/Kpts-II/1999 dan Nomor 598/Menhut-II/2009 menimbulkan konflik di antara berbagai pihak yang berkepentingan. Penelitian dengan pendekatan kualitatif ini ingin (1) memetakan persoalan (dinamika) akses, properti, kekuasaan, dan kewenangan atas SDA di Hutan Sesaot sebelum dan sesudah penetapan; (2) menganalisis struktur dan tahapan konflik serta relasi (kumpulan dan jaring-jaring) kekuasaan para aktor yang terlibat; (3) merekomendasikanskema pengelolaan kolaboratif sebagaisolusi penyelesaian konflik. Hasil penelitian menemukan bahwa konflik pengelolaan sumber daya alam di hutan Sesaot bersumber dari perebutan akses dan hak pengelolaan antara Pemerintah Provinsi Nusa Tenggara Barat dengan masyarakat lokal yang kemudian mendapat dukungan dari Pemerintah Kabupaten Lombok Barat. Dengan relasi, kumpulan, dan jaring kekuasaan yang dimilikinya, Pemprov NTB mendukung skema TAHURA, sedangkan Pemkab Lombok Barat mendukung skema HKm (Hutan Kemasyarakatan). Pihak ketiga berhasil meredakan konflik dengan keputusan mengembalikan status fungsi hutan Sesaot dengan skema $\mathrm{HKm}$ dan memindahkan lokasi TAHURA ke wilayah lain di luar kawasan hutan Sesaot. Namun, tidak semua pihak puas dengan keputusan ini. Untuk menghindari konflik terjadi lagi di masa yang akan datang, penulis menyarankan modifikasi skema HKm menjadi Hkm kolabaratif yang mampu menampung kepentingan semua pihak.
\end{abstract}

Kata kunci: ekologi politik, hutan kemasyarakatan (HKm), hutan Sesaot, konflik, pengelolaan kolaboratif 


\section{PENDAHULUAN}

Hutan Sesaot terletak di sebelah barat Taman Nasional Rinjani, memiliki luas 5.950,18 Ha, dan merupakan daerah tangkapan air dari DAS Dodokan. Secara administrasi, kawasan hutan ini terletak di Kecamatan Narmada dan Lingsar, Kabupaten Lombok Barat, dan diapit oleh empat desa, yaitu Sesaot, Lebah Sempage, Sedau, dan Batu Mekar. Berdasarkan SK Menteri Pertanian Nomor 756/ $\mathrm{Kpts} / \mathrm{Um} / 1982$, status dan fungsi hutan Sesaot adalah hutan lindung. Penetapan hutan Sesaot sebagai hutan Lindung didasarkan atas pertimbangan fungsi hutan sebagai sumber mata air bagi irigasi pertanian dan kebutuhan air bersih bagi rumah tangga, khususnya di Kota Mataram, Kabupaten Lombok Barat, dan sebagian Kabupaten Lombok Tengah (Galudra et al, 2010).

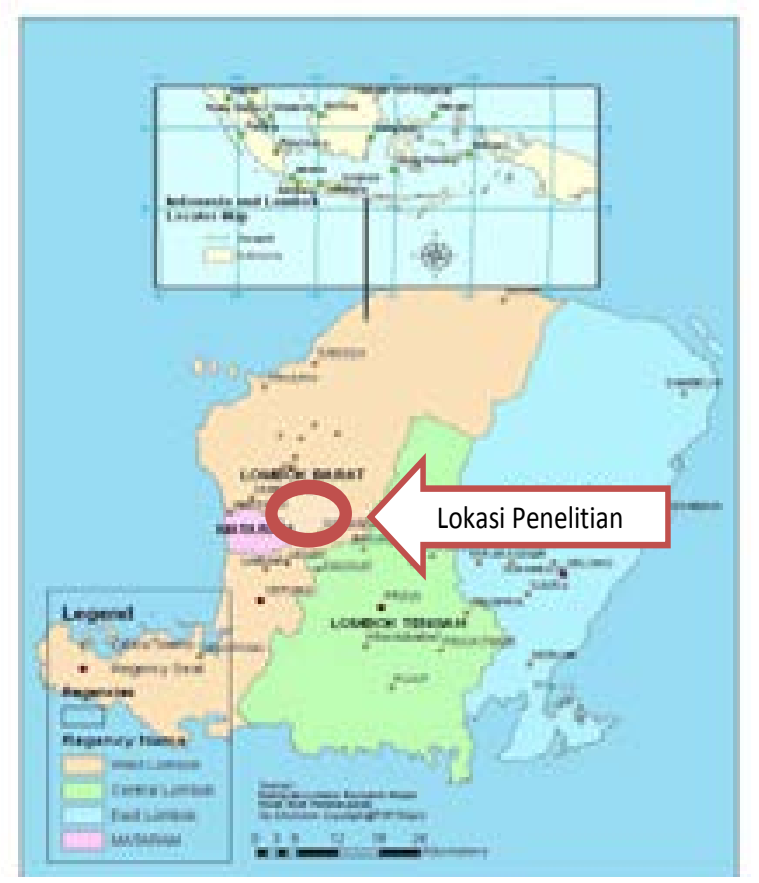

Gambar 1. Lokasi Hutan Sesaot, Lombok Barat Sumber: dimodifikasi dari Klock (2008)

Dalam perkembangan selanjutnya, adanya potensi wisata, seperti pemandian alam, air terjun, dan perkemahan; serta keanekaragaman hayati yang beragam, seperti lutung, kijang, kera, burung cabe lombok, dan juga beragam flora yang juga menambah atraksi dan daya tarik wisata di hutan Sesaot menyebabkan Pemerintah Daerah Provinsi NTB, dalam hal ini Gubernur NTB dan Dinas Kehutanan Provinsi NTB mengajukan hutan Sesaot untuk ditunjuk sebagai Taman Hutan Raya (TAHURA) Nuraksa seluas $3.155 \mathrm{Ha}$. Pengajuan ini kemudian mendapatkan pengakuan dari Kementerian Kehutanan melalui SK Menteri Kehutanan Nomor 224/ KPTS-II/1999 dan SK Menteri Kehutanan Nomor 598/ Menhut-II/2009. Namun, upaya ini mendapat penolakan dari pihak masyarakat sekitar hutan Sesaot dan Pemerintah Kabupaten Lombok Barat, terutama Bupati dan Dinas Kehutanan Kabupaten Lombok Barat. Konflik di antara kedua belah pihak pun tidak dapat dihindari

Berbagai hasil penelitian terdahulu menunjukkan konflik pemanfaatan atau pengelolaan SDA di
Indonesia disebabkan oleh masalah-masalah struktural dan kebijakan negara (pemerintah) dalam mengatur pengelolaan SDA. Adiwibowo dan Mardiana (2009) menunjukkan krisis ekologi dan konflik pengelolaan hutan negara di Kabupaten Wonosobo lebih banyak disebabkan masalah-masalah struktural serta kebijakan negara dalam memandang, memanfaatkan dan mengelola sumberdaya alam yang sangat kental diwarnai oleh berbagai kepentingan ekonomi, politik, dan militer negara yang tumpang tindih sejak masa kolonial Belanda hingga era desentralisasi. Kuswijayanti, Dharmawan, dan Kartodihardjo (2007) menunjukkan penetapan Taman Nasional Gunung Merapi (TNGM) melalui SK Menteri Kehutanan Nomor 134/2004 telah membatasi akses masyarakat lokal terhadap SDA di TNGM sehingga menimbulkan konflik dan benturan kepentingan antar berbagai pihak yang berkepentingan dengan TNGM. Zainudin, Soetarto, Adiwibowo, dan Pandjaitan (2012) mengemukakan bahwa konfrontasi konflik SDA di Poboya terjadisetelah terbitnya SK Menteri Kehutanan Nomor 461/Kpts-II/1995 yang menetapkan kawasan Poboya dan sekitarnya sebagai TAHURA Palu dan SK Menteri Kehutanan Nomor 24/KptsII/1999 yang kembali mengukuhkan kawasan Poboya sebagai TAHURA Sulawesi Tenggara. Krisis konflik semakin berlanjut ketika pemerintah mulai melakukan penertiban terhadap aktivitas masyarakat dalam memanfaatkan SDA di Poboya, termasuk penutupan penambangan emas tradisional milik masyarakat lokal. Aji et al. (2011) menyampaikan bahwa keterbatasan akses dan kontrol terhadap SDA membuat masyarakat desa sekitar hutan negara menjadi termarginalisasi, tertinggal, terekslusi, dan tidak jarang harus berbenturan (berkonflik) dengan negara sebagai "pemilik" hutan.

Sebagai solusi, Adiwibowo dan Mardiana (2009) kemudian memberikan jalan keluar untuk mereduksi konflik sekaligus membuka jalan pengentasan kemiskinan masyarakat sekitar hutan Wonosobo melalui pengelolaan kolaboratif. Pengelolaan kolaboratif dipandang lebih dari sekedar partisipasi dari para pemangku kepentingan. Bentuk kelembagaan kolaboratif dibangun bersama oleh para aktor berkepentingan untuk melakukan penataan akses dan kontrol sumberdaya hutan di Wonosobo. Sementara itu, Aji et al. (2011) mempromosikan pengembangan social forestry sebagai sebagai solusi atas keterbatasan akses dan kontrol atas SDA yang kemudian dapat mengurangi konflik dan kemisikinan di desa-desa sekitar hutan.

Dari uraian di atas, studi ini bertujuan: 1. Memetakanpersoalan (dinamika) akses, properti, kekuasaan, dan kewenangan atas SDAdi Hutan Sesaot sebelum dan sesudah penetapan menjadi TAHURA.

2. Menganalisisstrukturdantahapankonflikpengelolaan SDA di Hutan Sesaot serta relasi (kumpulan dan jaring-jaring) kekuasaan para aktor yang terlibat.

3. Merekomendasikanskema HKm Kolaboratif sebagaisolusi penyelesaian konflik pengelolaan SDA yang terjadi di hutan Sesaot.

\section{LANDASAN TEORI}

\section{Teori Akses}

Ribot dan Peluso (2003) mendefinisikan akses sebagai "kemampuan untuk memperoleh manfaat dari segala 
sesuatu (the ability to derive benefit from things), termasuk objek material, individu/orang, institusi, dan simbol dengan memfokuskan pada kemampuandan authority dibandingkan dengan kepemilikan yang ada dalam teori properti. Teori akses digunakan untuk menganalisis siapa yang sebenarnya mendapat manfaat dari sumberdaya serta mengidentifikasi konstelasi cara, relasi, dan proses berbagai aktor untuk memperoleh manfaat dari sumberdaya yang ada. Hal ini menunjukkan kuatnya dimensi kekuasaan atau kumpulan kekuasaan (bundle of powers) dan juga jaring kekuasaan (webs of power) yang ditopang oleh unsur-unsur budaya, ekonomi, dan politik yang membentuk jairngan kepentingan dan membangun relasi sosial untuk mendapatkan akses SDA. Kekuasaan (power) tersebut diwujudkan dan dilakukan melalui berbagai mekanisme, proses, dan hubungan sosial yang mempengaruhi kemampuan orang untuk mendapatkan keuntungan dari sumber daya.

Teori Dinamika Access, Property, Power, dan Authority

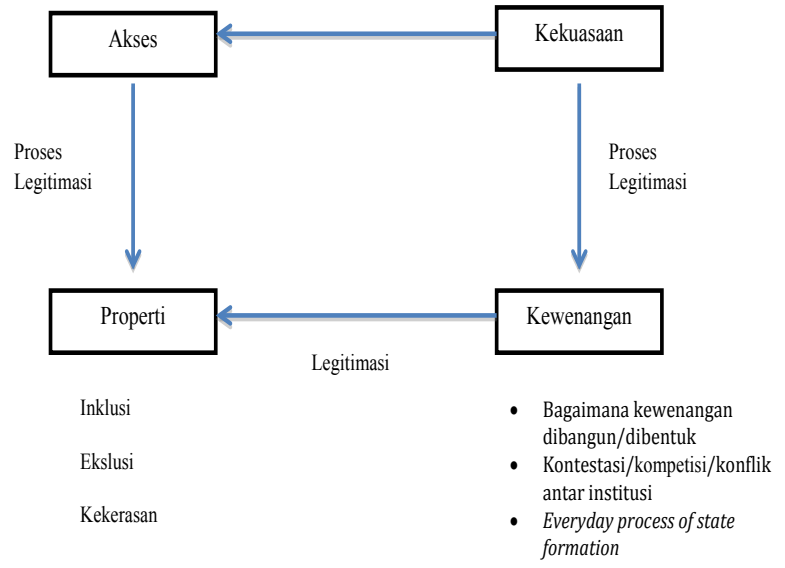

Gambar 2. Kerangka Pemikiran

Teori Access Property, Power, and AuthoritySikor dan Lund (2009)

Sumber: diadaptasi dari Adiwibowo

Sikor dan Lund (2009) menyatakan bahwa akses dan properti mengenai sumberdaya alam secara berkaitan dengan kekuasaan (power) dan kewenangan (authority). Proses perebutan akses dan proses legitimasi atas properti (kepemilikan) berdampak pada kontestasi kekuasaan dan power. Siapa yang punya kekuasaan dan kewenangan akan sangat mudah menentuakan siapa yang akan mendapatkan akses dan properti serta siapa yang akan tereksklusi. Bagaimana kekuasaan dan kewenangan diberikan kepada institusi politik-hukum menjadi sesuatu yang sangat penting. Hal ini kemudian menghadirkan kontestasi dan konflik antar aktor/institusi.

\section{Teori Konflik Pengelolaan SDA}

Teori tentang konflik dapat dilacak melalui pemikiran scholars sosiologi, seperti Karl Marx, Emile Durkheim, Max Weber, George Simmel, Dahredrof, Coser, Ritzer, Camara, dll. Namun, dalam paper ini penulis akan menggunakan teori konflik yang diusung Fisher (2001). Menurut Fisher (2001) dalam Zainuddin et al (2012), pemicu terjadinya konflik dapat dikelompokkan ke dalam dua teori, yaitu (i) teori kebutuhan manusia yang tidak terpenuhi atau terhalangi, seperti livelihood, keamanan, identitas, pengakuan, partisipasi, dan otonomi; dan (ii) teori transformasi konflik. Teori yang kedua berasumsi bahwa konflik yang terjadi disebabkan karena adanya ketidaksetaraan dan ketidakadilan yang muncul sebagai masalah sosial, budaya, dan ekonomi.

Lebih lanjut, Fisher mengemukakan bahwa pola konflik dapat dikategorikan ke dalam tiga bentuk, yaitu (i) konflik laten yang sifatnya tersembunyi dan perlu diangkat ke permukaan sehingga dapat ditangani secara efektif; (ii) konflik terbuka yang berakar dalam dan sangat nyata serta memerlukan berbagai tindakan untuk mengatasi akar penyebab dan berbagai macam dampaknya; dan (iii) konflik di permukaan memiliki akar yang dangkal atau tidak berakar dan muncul hanya karena kesalahpahaman mengenai sesuatu yang dapat diatasi dengan komunikasi yang baik dan intensif.

Untuk lebih memahami dan memudahkan analisis, Fisher membagi tahapan-tahapan ke dalam empat fase konflik yang mempunyai aktivitas, intensitas, ketegangan, dan kekerasan yang berbeda. Fase-fase konflik tersebut, yaitu:

1. Fase Pra-Konflik. Fase ini merupakan periode di mana terdapat suatu ketidaksesuaian sasaran di antara kedua pihak atau lebih, sehingga timbul konflik. Konflik tersembunyi dari pandangan umum, meskipun salah satu pihak atau lebih mungkin mengetahui potensi terjadinya konfrontasi. Mungkin terdapat ketegangan hubungan di antara beberapa pihak dan/atau keinginan untuk menghindari kontak satu sama lain.

2. Fase Konfrontasi. Fase ini terjadi pada saat konflik menjadi semakin terbuka. Para pendukungnya mulai melakukan demonstrasi atau perilaku konfrontatif lainnya.

3. FaseKrisis.Faseinimerupakanfasepuncakterjadinya konflik ketika ketegangan dan/atau kekerasan terjadi sangat hebat. Komunikasi normal di antara dua pihak kemungkinan putus, pernyataan-pernyataan umum cenderung menuduh dan menentang pihak lain.

4. Fase Akibat. Pada fase ini kedua pihak mungkin setuju bernegosiasi dengan atau tanpa perantara. Satu pihak yang mempunyai otoritas / kewenangan atau pihak ketiga yang berkuasa mungkin akan memaksa kedua belah pihak untuk mengentikan pertikaian.

5. Fase Pasca-Konflik. Fase ini merupakan akhir dari konflik yang terjadi. Ketegangan berkurang dan tidak ada lagi konfrontasi kekerangan. Hubungan kedua belah pihak mengarah kepada kondisi normal. Namun, jika isu-isu dan masalah-masalah pemicu konflik muncul kembali dan saling betentangan, fase ini seringkali kembali lagi menjadi fase pra-konflik.

\section{METODE}

Penelitian dilakukan melalui pendekatan kualitatif dengan mengambil kasus konflik pengelolaanSDA di Hutan Sesaot, Kabupaten Lombok Barat, Provinsi Nusa Tenggara Barat pasca penetapan kawasan Hutan Sesaot menjadi kawasan Taman Hutan Raya (TAHURA) melalui SK Menteri Kehutanan dan Perkebunan Nomor 244/Kpts-II/1999 tentang Perubahan Fungsi Kawasan Hutan Lindung Sesaot Menjadi TAHURA dan SK Menteri Kehutanan Nomor 598/Menhut-II/2009 tentang 
Penunjukan Kawasan Hutan dan Konservasi Perairan NTB. Data yang digunakan dalam paper ini adalah datadata primer dan sekunder yang diperoleh penulis ketika melakukan penelitian dengan judul Model Pengurangan Kemiskinan di Desa-desa Sekitar Hutan: Pengembangan Social Forestry di Jawa Barat dan Lampung pada tahun 2011 yang merupakan bagian dari Program Penelitian Kompetitif-Sub Program Critical and Strategic Social Issues-Lembaga Ilmu Pengetahuan Indonesia. Penelitian lapangan di Kawasan Hutan Sesaot merupakan upaya peneliti untuk mendapatkan pembelajaran mengenai model pengelolaan hutan di NTB. Pengumpulan data primer dilakukan melalui wawancara mendalam dengan sejumlah elit lokal sebagai tokoh kunci yang dianggap memahami permasalahan yang ada di Hutan Sesaot, FGD di tingkat kelompok petani pemanfaat Hutan Sesaot, FGD multi-stakheloders yang terkait dengan permasalahan Hutan Sesaot yang dilakukan di NTB, dan observasi langsung peneliti melalui transek di kawasan Hutan Sesaot pada bulan November 2011. Selain itu, untuk melakukan validasi data, peneliti melakukan FGD multi-stakheolders yang dilakukan di Jakarta pada akhir tahun 2011. Data yang ada tersebut kemudian dilengkapi lagi melalui pengumpulan data sekunder terbaru yang dilakukan pada 27-31 Januari 2014

Data penelitian tersebut kemudian dianalisis menggunakan teori-teori ekologi politik danpengelolaan sumberdaya alam berbasis masyarakat, yaitu Teori Akses Ribot dan Peluso (2003), Teori Kepemilikan Hak (properti right) Ostrom (1990), Teori Akses dan Kepemilikan (access \& property) Sikor dan Lund (2009), dan Teori Model Pengelolaan Sumberdaya Alam Birner dan Wittmer dalam Satria (2012). Selain itu, untuk menganalisis konflik pemanfataan sumberdaya alam yang terjadi, penulis menggunakan Teori Konflik Fisher (2001) dalam Zainuddin et al (2012).

\section{TEMUAN DAN HASIL}

\section{SejarahPenguasaan dan Pengelolaan SDA di Hutan Sesaot}

Selain mempunyai peran penting sebagai daerah tangkapan air baik untuk sumber air bersih dan irigasi seperti yang disampaikan pada pendahuluan, hutan Sesaot mempunyai arti penting bagi perekonomian dan kehidupan masyarakat sekitarnya, terutama bagi masyarakat empat desa yang mengapitnya, yaitu Sesaot Lebah Sempage, Sedau, dan Batu Mekar. Sejak tahun 1957, masyarakat sudah terlibat dalam pengelolaan hutan Sesaot. Masyarakat ikut menanam tanaman sengon dan buah-buahan sebagai bagian dari program rehabilitasi. Masyarakat tidak hanya ikut menanam, namun juga diperkenankan mengelola tanaman tersebut. Pada tahun 1968-1969, masyarakat mulai menanm kopi di bawah tegakkan pohon penghijauan. Agar penanaman kopi dikelola dengan baik, pada tahun 1972 kantor kehutanan setempat mendirikan Koperasi Rimbawan yang menaungi pengelolaan kopi masyarakat. Sejak saat itu, livelihood masyarakat lokal sekitar hutan Sesaot ditopang oleh kopi. Mulai tahun 1975, rehabilitasi lahan untuk seluruh kawasan hutan dalam hutan produksi Sesaot dilakukan dengan sistem tumpangsari. Masyarakat lokal diminta bantuan menanam dan memelihara tanaman pokok yang bibitnya diberikan oleh kantor kehutanan dengan tidak diberi upah. Sebagai kompensasi, masyarakat lokal yang terlibat diberikan kesempatan selama tiga tahun untuk menanam tanaman semusim di sela-sela tanaman pokok. Tanaman tumpangsari yang paling banyak ditanam pada waktu itu adalah padi gogo (rau). Sehingga ada istilah ngegrau untuk aktivitas menanam di hutan. Jenis tanaman tumpangsari lainnya adalah kacang-kacangan, kecipir, dan jagung.

Selain bergantung pada kopi dan tanaman semusim di selasela tanaman pokok, masyarakat lokal juga terlibat sebagai buruh tebang dan buruh pikul pada perusahan HPH yang mendapatkan konsesi pengelolaan hutan Sesaot. Pada tahun 1982 terjadi perubahan status danfungsi hutan Sesaot dari hutan produksi menjadi hutan lindung melalui SK Menteri Pertanian Nomor 756/Kpts/Um/1982. Meskipun menghilangkan peluang kerja sebagai buruh tebang dan buruh pikul pada perusahaan $\mathrm{HPH}$, namun perubahan status dan fungsi ini tidak serta merta menghilangkan akses pengelolaan masyarakat lokal terhadap SDA hutan Sesaot. Pemerintah melibatkan masyarakat lokal dalam program penghijauan di wilayah eks-HPH hutan Sesaot. Tanaman mahoni, sengon, lamtoro, dan juga tanaman buah-buahan ditanam melalui mekanisme banjar harian dan tumpang sari (agroforestri). Bahkan, masyarakat menanam pisang di antara tanaman-tanaman tersebut.

Untuk penanaman dan pengelolaann kopi pun terus berlanjut. Luas tanaman kopi di hutan Sesaot pada hingga tahun 1985 sudah mencapai 1.662 Ha sehingga pemerintah melaluiSK GubernurNTBNomor 140/1986 danSKKepala Dinas Kehutanan NTB Nomor 522.21/5358 memberikan akses pemanfaatan hak pengelolaan lahan seluas 1.623,40 Ha di kawasan penyangga hutan lindung Sesaot kepada $1.493 \mathrm{KK}$ masyarakat lokal untuk terus ditanami kopi dengan diikat oleh perjanjian. Masyarakat yang memelihara tanaman kopi tersebut berhak mendapatkan bagi hasil sebesar 50 persen dari hasil panen kopi.

Terinspirasi oleh SK Menteri Kehutanan Nomor 622/ Kpts-II/1994, pada tahun 1995 dilakukan uji coba pengelolaan HKm di hutan Sesaot seluas 25 Ha yang melibatkan 58 penggarap melalui pendampingan LP3ES NTB yang dilanjutkan oleh LSM Konsepsi. Uji coba $\mathrm{HKm}$ tersebut kemudian diperkuat dengan SK Gubernur NTB Nomor 140/1996. Uji coba HKm selanjutnya dikembangkan tahun 1998 pada areal seluas $211 \mathrm{Ha}$ dengan jumlah penggarap 1.244 KK.

\section{Pencabutan Akses terhadap Sumberdaya Hutan sebagai Sumber Konflik Pengelolaan Hutan Sesaot}

Pemberian akses dan hak pengelolaan atas lahan dan SDA hutan Sesaot melalui penanaman kopi, tumpang sari tanaman semusim, dan kemudian uji coba HKm oleh pemerintah menghasilkan keberlanjutan livelihood masyarakat lokal dan juga kelestarian hutan Sesaot. Kondisi ini merupakan masa-masa indah, damai, dan cerah. Pemerintah dan masyarakat lokal bisa saling berdampingan mengelola dan mengambil manfaat dari hutan Sesaot. Namun, masa-masa ini mendadak berubah menjadi masa-masa yang kelam dan penuh konflik setelah Pemerintah NTB mengirim surat rekomendasi No 660/305/ Bapedalda/1998 kepada Menteri Kehutanan agar ditetapkan sebagai TAHURA. Rekomendasi disetujui Kementerian Kehutanan (waktu itu masih bernama Departemen Kehutanan dan Perkebunan) melalui SK Menteri Kehutanan dan Perkebunan Nomor 318/Kpts-II/1999. 
Menurut UU Nomor 5/1990 tentang Konservasi Sumberdaya Alam Hayati dan Ekosistemnya dan PP Nomor 68/1998, TAHURA didefinisikan sebagai kawasan pelestarian alam untuk tujuan koleksi tumbuhan dan atau satwa yang alami atau bukan alami, yang dimanfaatkan bagi kepentingan penelitian, ilmu pengetahuan, dan pendidikan, menunjang budidaya, budaya, pariwisata, dan rekreasi. Dari definisi tersebut TAHURA berfungsi sebagai kawasan konservasi yang hanya bertujuan untuk penelitian, pendidikan, koleksi tumbuhan dan satwa, pariwisata, budaya dan pelestarian. Pengelolaan TAHURA hanya bisa dilakukan/ dimanfaatkan pemerintah atau diserahkan pengelolaannya kepada pihak ketiga (pengusaha/investor). Akibatnya, masyarakat lokal tidak mendapat peluang bahkan kehilangan akses terhadap pengelolaan dan pemanfaatan hutan Sesaot yang menjadi kawasan TAHURA.

Akses dan hak pengelolaan SDA di hutan Sesaot yang dimiliki masyarakat lokal sejak tahun 1957, bahkan sejak zaman penjajahan Belanda mendadak dicabut. Berbagai perjanjian antara masyarakat lokal dengan pemerintah, termasuk yang terakhir-yaitu dalam mekanisme uji coba HKm-menjadi terancam. Sebagai konsekuensi, Pemerintah Provinsi NTB, dalam hal ini Dinas Kehutanan Provinsi sebagai pengelola TAHURA harus melakukan sterilisasi kawasan hutan Sesaot dengan mengekslusi masyarakat lokal dari kegiatan penanaman kopi, tumpang sari, dan kegiatan apapun di luar fungsi TAHURA.

Tahapan Konflik Pengelolaan SDA di Hutan Sesaot Uraian yang disampaikan di atas mengenai pencabutan akses dan hak pengelolaan masyarakat lokal terhadap SDA di hutan Sesaot sebagai konsekuensi ditetapkannya hutan Sesaot merupakan fase pertama dalam tahapan konflik menurut Fisher (2001). Fisher menyebutnya dengan fase pra-konflik. Pada fase ini, terdapat perbedaaan pandangan atau ketidak ketidaksesuaian tujuan. Hal ini terlihat dari penolakan masyarakat lokal dan Pemerintah Kabupaten Lombok Barat yang dimotori oleh Dinas Kehutanan Kabupaten yang menolak penetapan hutan Sesaot sebagai TAHURA yang mengancam akses dan hak pengelolaan masyarakat lokal terhadap SDA di hutan Sesaot. Menurut Pemerintah Kabupaten Lombok Barat TAHURA tidak mampu mengakomodir akses dan hak pengelolaan masyarakat lokal terhadap SDA hutan Sesaot yang selama ini telah diberikan pemerintah dan dimiliki oleh masyarakat lokal, apalagi sejak 1998 sebanyak 1.244 KK masyarakat lokal telah mendapatkan izin HKm.

Fase kedua: konfrontasi. Konfrontasi konflik mulai terjadi ketika pada tahun 1999 terjadi pengambil-alihan secara paksa areal pengelolaan HKm yang dikelola masyarakat lokal oleh Pemerintah Provinsi NTB untuk dijadikan areal penangkaran rusa. Konfrontasi berlanjut pada tahun 2010 ketika Pemerintah Provinsi NTB membangun Gapura "TAHURA Nuraksa" sebagai simbol dan penegasan bahwa hutan Sesaot telah menjadi kawasan TAHURA. Pemerintah Provinsi NTB kemudian mengeluarkan pernyataan akan mengusir masyarakat lokal dari hutan Sesaot. Masyarakat lokal dan Pemerintah Kabupaten Lombok Barat pun tidak tinggal diam. Masyarakat lokal kemudian merapatkan barisan dengan semakin memperkuat institusi modern dan institusi indegenous masyarakat lokal. Penguatan institusi modern dilakukan dengan memperkuat organisasi lokal KMPH (Kelompok Masyarakat Pelestari Hutan). KMPH awalnya merupakan gabungan dari kelompok tani hutan di Desa Sesaot, Desa Lebah Sempage, dan Desa Sedau yang menjadi peserta uji coba HKm pada tahun 1995. Penguatan institusi indigenous dilakukan dengan menegakkan awig-awig pengelolaan hutan Sesaot. Nama "TAHURA Nuraksa" yang dipasang pada gapura di pintu masuk kawasan hutan Sesaot pun dicopot dan diganti masyarakat dengan nama "HKm".

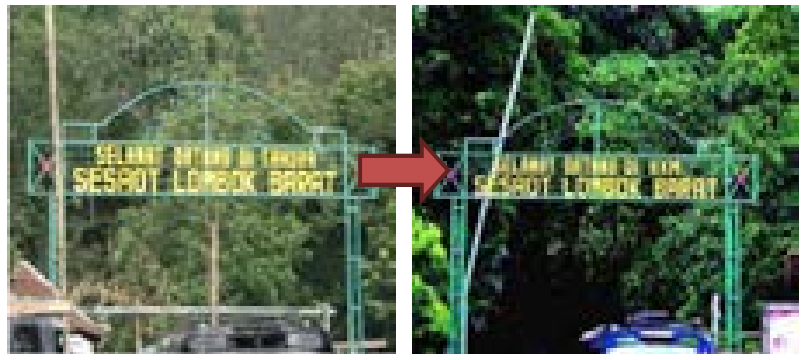

Gambar 3. Penggantian Nama "TAHURA" dengan "HKm" oleh Masyarakat Lokal sebagai Bentuk Penolakan TAHURA

Sumber: 3a. SCFWM (2010) dan 3b. Warman et al (2012)

Fase ketiga: krisis. Setelah beberapa kali terjadi konfrontasi antara Pemerintah Provnsi NTB yang dimotori Dinas Kehutanan Provinsi dan masyarakat lokal yang didukung Pemerintah Kabupaten Lombok Barat yang dimotori Dinas Kehutanan Kabupaten konflik terus terjadi dan semakin memanas. Ketegangan di antara kedua belah pihak menjadi semakin menguat. Dengan kekuasan (power) yang dimilikinya, kedua belah pihak mengeluarkan berbagai kebijakan yang menguatkan posisinya dan menentang/melemahkan lawan. Berbagai pernyataan dikeluarkan kedua belah pihak untuk menuduh dan menentang pihak lain.

Sejak awal tahun 2000 terjadi pembalakan kayu besarbesaran di kawasan hutan Sesaot sehingga hutan Sesaot mengalami kerusakan yang parah. Dinas Kehutanan Provinsi menuding bahwa hal ini disebabkan oleh aktivitas penebangan kayu oleh masyarakat lokal sehingga Dinas Kehutanan Provinsi melalui Surat Nomor 1480/VI-PHA/2000 tanggal 3 Juli 2000 mengusulkan perlunya pemanfaatan limbah kayu curian dari hutan Sesaot kepada Gubernur NTB. Melalui SK Gubernur Nomor 522/629/EKO/200 tentang Pemanfaatan Kayu Bekas Perambahan dan Pencurian di Kawasan Hutan Sesaot, Gubernur NTB menyetujui usulan dari Dinas Kehutanan Provinsi. Menanggapi SK Gubernur tersebut, Dinas Kehutanan Provinsi mengeluarkan Surat Nomor 522.21/546/Dishut tentang Pelaksanaan Pemanfaatan dan Penjualan Kayu-kayu Produksi Swakelola.

Mengenai penuduhan masyarakat lokal sebagai pembalak kayu dan perusak hutan Sesaot yang disampaiak Dinas Kehutanan Provinsi dalam berbagai kesempatan dan media massa lokal mendapat perlawanan dari masyarakat lokal dan juga Pemerintah Kabupaten Lombok Barat. Masyarakat lokal yang diwakili KMPH menyuarakan pembelaan, tanggapan, dan klarifikasi melalalui beberapa surat resmi yang ditujukan kepada Kepala Dinas Kehutanan Provinsi NTB, Bupati Lombok Barat, dan redaksi media massa lokal. Penulis berhasil 
mendapatkan sedikitnya tiga surat berbeda mengenai hal ini. Menanggapi kondisi ini, Bupati Lombok Bara kemudian mengeluarkan Surat Nomor 180/04/Kum/2000 mengenai perintah penghentian eksploitasi hutan lindung Sesaot yang ditujukan kepada Kepala Dinas Kehutanan Kabupaten Lombok Barat yang ditembuskan kepada Gubernur NTB, Ketua DPRD Provinsi NTB, dan Kepala Dinas Kehutanan Provinsi. Dalam surat itu, Bupati Lombok Barat juga menyatakan bahwa pengelolaan hutan Sesaot sejak tahun 1998 sudah menjadi kewenangan Kabupaten Lombok Barat sesuai pasal 5 PP Nomor 62/1998 tentang Penyerahan Sebagian Urusan Pemerintahan di Bidang Kehutanan Kepada Daerah.

Melihat fakta dan fenomena ini, LP3ES NTB yang sejak 1995 ikut melakukan pembinaan terhadap masyarakat lokal di sekitar hutan Sesaot akhirnya ikut turun turun tangan. Pada tanggal 18 Oktober 2000, LP3S NTB mengeluarkan pernyataan pers yang menyatakan bahwa tuduhan kepada masyarakat lokal sebagai pembalak kayu dan perusak hutan Sesaot sehingga Dinas Kehutanan Provinsi mengeluarkan Surat Nomor 1480/VI-PHA/2000 adalah tidak benar. Oleh karena itu, LP3ES menuntut (i) penghentian kegiatan pemanfaatan limbah kayu hutan Sesaot melalui pencabutan atau pembatalan seluruh bentuk surat keputusan atau surat menyurat yang menjadi dasar hukum (legalitas) bagi pihak kehutanan untuk mengeluarkan kayu dari hutan Sesaot; (ii) Dinas Kehutanan melakukan upaya rehabilitasi atas kawasan hutan yang telah rusak dengan mengoptimalkan peran masyarakat baik melalui KMPH maupun pemerintahan desa sebagai pengelola hutan Sesaot; dan (iii) meminta seluruh pejabat kehutanan dari provinsi hingga desa yang bertanggungjawab atas keamanan dan kelestarian fungsi hutan untuk mengundurkan diri dari jabatannya sebagai wujud dari pertanggungjawaban moral.

Pada tanggal 19 Oktober 2000 dilakukan pembentukan Tim Penanganan Hutan Sesaot Kabupaten Lombok Barat oleh Bupati Lombok Barat di Aula Kantor Bupati Lombok Barat. Tim terdiri dari unsur stakheloders tingkat kabupaten (muspida), tingkat Kecamatan (muspika) Narmada, pemerintahan desa (Sesaot, Lb. Sempaga, dan Sedau) dan kelompok masyarakat lokal (KMPH). LP3ES NTB ikut menjadi salah satu elemen yang menginisiasi pembentukan tim ini. Tim pun mulai bekerja, mulai dari mengunjungi hutan Sesaot dan berdialog dengan masyarakat lokal Sesaot sampai upaya-upaya untuk menyelesaikan status TAHURA dan mengembalikannya menjadi hutan lindung serta memastikan pengelolaan hutan Sesaot di bawah Pemerintah Kabupaten Lombok Barat, bukan di bawah Pemerintah Provinsi NTB.

Harapan baru mulai muncul. Tanggal 11 Juni 2001 SK Dirjen PHKA-Kementerian Kehutanan Nomor SK.579/ $\mathrm{DJ}-\mathrm{V} / \mathrm{KK} / 2001$ mengenai penyerahan pelimpahan kewenangan pengelolaan TAHURA Nuraksa Sesaot dari Pemerintah Provinsi NTB ke Pemerintah Kabupaten Lombok Barat. Meskipun statusnya tetap TAHURA, namun ini menjadi angin segar bagi Pemerintahan Lombok Barat. Pada tahun 2003, Pemerintah Kabupaten Lombok Barat kemudian menerbitkan Perda Nomor 10/2003 yang memberikan gerak kepada masyarakat lokal untuk mengelola hutan dengan pola $\mathrm{HKm}$. Pemerintah Kabupaten Lombok Barat masih berasumsi bahwa hutan Sesaot berfungsi sebagai hutan lindung.
Untuk memperjuangkan legalitas HKm, Pemerintah Kabupaten Lombok Barat melakukan komunikasi dan meminta dukungan yang intensif dengan Direktorat Jendral (Dirjen) Rehabilitasi Lahan dan Perhutanan Sosial (RLPS)-Kementerian Kehutanan yang mempunyai kewenangan dalam program $\mathrm{HKm}$ dan perhutanan sosial lainnya. Hasilnya, pada tahun 2009 terbit SK Menteri Kehutanan Nomor 445/Menhut/2009 tentang Penetapan Areal Kerja HKm seluas $185 \mathrm{Ha}$ di Kabupaten Lombok Barat. Mendapat dukungan dari Dirjen RLPS-Kementerian Kehutanan, Pemerintah Kabupaten Lombok Barat kemudian mengeluarkan SK Bupati Nomor 2130/65/Dishut/2009 tentang Pemberian Izin Usaha Pengelolaan HKm kepada KMPH Mitra Sesaot Desa Sesaot, Lebah Sempaga, dan Sedau.

Namun, pada saat bersamaan, Pemerintah Provinsi NTB yang dimotori Dinas Kehutanan Provinsi tetap ngotot dan tidak mau kalah. Dinas Kehutanan Provinsi mengklaim kawasan hutan Sesaot adalah tetap sebagai TAHURA dengan argumen bahwa SK Menteri Kehutanan Nomor 53/2008 menyebutkan bahwa penunjukkan parsial lebih kuat secara hukum daripada penunjukkan kawasan. Pemerintah Provinsi NTB kemudian memperkuat kewenangan pengelolaan hutan Sesaot dengan mengeluarkan Peraturan Gubernur Nomor 23/2008 yang mengatur pengelolaan hutan Sesaot dilakukan oleh Unit Pelaksana Teknis Daerah (UPTD) Balai Taman Hutan Raya Nuraksa-Dinas Kehutanan Provinsi. Selain memperkuat posisi dan kewenangannya di daerah, Dinas Kehutan Provinsi terus meminta dukungan dari Ditjen Perlindungan Hutan dan Konservasi Alam (PHKA)-Kementerian Kehutanan. Dengan dukungan Ditjen PHKA-Kementerian Kehutanan, legalitas pembentukan TAHURA Nuraksa kembali diperkuat melalui SK Menteri Kehutanan Nomor 598/MenhutII/2009 yang mengubah status hutan lindung Sesaot menjadi TAHURA. Untuk memperkuat status di daerah, Pemerintah Provinsi NTB menerbitkan Perda Nomor 3/2010 yang merupakan hasil kesepakatan antara Pemerintah Pusat dan Pemerintah Provinsi.

Keluarnya legalitas penguatan TAHURA dan penegasan kembali dari Pemerintah Provinsi NTB bahwa pengelolaan hutan Sesaot dalam bentuk TAHURA di bawah kewenangan UPTD Balai Taman Hutan Raya Nuraksa-Dinas Kehutanan Provinsi membuat ketegangan semakin memuncak. Pemerintah Kabupaten Lombok Barat dalam hal ini Bupati pada tanggal 19 Mei 2010 kembali menyurati Ditjen RLPS melalui Surat Nomor 522/726/Dishut/2010 untuk meminta dukungan atas program HKm di hutan Sesaot. Dalam surat itu, Bupati mengusulkan pencadangan areal kerja baru HKm di hutan Sesaot seluas 3.672 Ha untuk 3.402 KK.

Masyarakat lokal pun tidak ketinggalan merapatkan barisan. Masyarakat lokal konsisten untuk menolak TAHURAdanmenginginkantetapdilanjutkannya program HKm. Fasilitasi SCBFWM untuk pengembangan model TAHURA berbasis masyarakat pada September 2010 tetap ditolak masyarakat lokal Sesaot. Masyarakat lokal pengguna Sesaot kemudian mengirimkan surat pernyataan penolakan pembentukan TAHURA kepada Gubernur NTB yang ditembuskan kepada Dirjen RLPS, Bupati Lombok Barat, dan Ketua DPRD Provinsi dan Kabupaten.

Selainbertarungsecararesmimelaluijalurkebijakan, kedua 
belah pihak terus bertarung lewat pernyataan-pernyataan di media massa lokal Hasil analisis terhadap beberapa artikel pemberitaan menunjukkan kedua belah pihak tetap tidak mau mengalah. Bahkan, beberapa kali masyarakat lokal sesaot melakukan unjuk rasa untuk menolak TAHURA dan pengakuan HKm. Pada 16 Desember 2010, misalnya, sekitar 1.000 orang masyarakat sekitar hutan Sesaot berunjuk rasa di depan kantor Gubernur NTB menolak TAHURA dan menuntut izin $\mathrm{HKm}$.

Fase keempat: akibat. Pada fase ini, Fisher (2001) menyebutkan kedua pihak mungkin setuju bernegosiasi dengan atau tanpa perantara. Satu pihak yang mempunyai otoritas/kewenangan atau pihak ketiga yang berkuasa mungkin akan memaksa kedua belah pihak untuk mengentikan pertikaian.

Dalam kasus konflik pengelolaan hutan Sesaot, LP3ES NTB yang telah bertransformasi menjadi KONSEPSI (Konsorsium untuk Studi dan Pengembangan Partisipasi) NTB bertindak sebagai fasilitator atau disebut Fisher sebagai perantara untuk menyelesaikan konflik yang terjadi lebih dari 10 tahun. KONSEPSI bermitra dengan Ford Foundation, ACCES Phase II, LEI, ICRAF, FKKM, ICEL, FFI, Dewan Kehutanan Nasional, World Neighbors dan Lapera menyelenggarakan Sangkep Beleqatau pertemuan akbar yang mempertemukan Kelompok Pendukung TAHURA dan Kelompok Pendukung HKm pada tanggal 28-29 Desember 2010. Konsolidasi lanjutan kemudian dilakukan pemerintah melalui Kementerian Kehutanan pada 24 Januari 2011 di Gedung Manggala Wanabakti, Jakarta. Hasilnya, $\mathrm{HKm}$ pun direkomendasikan diteruskan dan TAHURA direkomendasikan dipindah ke Sumbawa. Di selasela Rapat Kerja Bappeda se-NTB, Kepala Bappeda NTB mengatakan bahwa Pemerintah Provinsi NTB akan melaksanakan kesepakatan dan rekomendasi yang dihasilkan Sangkep Beleq 28 Desember 2010 dan konsolidasi lanjutan 24 Januari 2011 di Gedung Manggala Wanabakti, Kementerian Kehutanan, Jakarta. Menindaklanjuti hasil dua pertemuan ini, Pemerintah Provinsi NTB akhirnya membuat keputusan bahwa kawasan hutan Sesaot akan diusulkan kembali menjadi hutan lindung dengan model $\mathrm{HKm}$ dan memindahkan lokasi TAHURA Provinsi NTB ke wilayah lain. Keputusan ini pertama kali disampaikan Kepala Bappeda Provinsi NTB dalam Rapat Kerja Bappeda se-NTB tanggal 29 Januari 2011 dan dirilis secara resmi di dalam website resmi Provinsi NTB tanggal 30 Januari 2011.

Fase kelima: pasca-konflik. Menurut Fisher, fase ini merupakan akhir dari konflik yang terjadi. Ketegangan berkurang dan tidak ada lagi konfrontasi ketegangan. Hubungan kedua belah pihak mengarah kepada kondisi normal. Hal ini juga terjadi pada saat penulis melakukan penelitian lapangan. Dalam beberapa kali FGD pada bulan November 2011 yang menghadirkan peserta dari Dinas Kehutanan Provinsi, Dinas Kehutanan Kabupaten, KONSEPSI, akademisi Universitas Mataram, dan perwakilan masyarakat lokal (KMPH), penulis menemukan "seyum lebar" yang penuh harapan atas masa depan hutan Sesaot dan juga kesejahteraan masyarakat lokal di sekitarnya. Bagi mereka, konflik yang terjadi sejak tahun 1999-2010 merupakan pelajaran berharga yang menguji persaudaran mereka. Mereka akhirnya sadar bahwa sebetulnya tujuan mereka sama yaitu ingin mewujudkan hutan Sesaot yang lesatri bagi keberlanjutan pembangunan dan kehidupan masyarakat NTB sekarang dan di kemudian hari.

Meskipun Fisher mengatakan bahwa jika isu-isu dan masalah-masalah pemicu konflik muncul kembali dan saling betentangan, seringkali akan mengulang kembali konflik, namun penulis berharap dan juga optimis bahwa kedamaian dalam pengelolaan SDA di hutan Sesaot akan berjalan selamanya, selama kebijakan pemerintah terhadap pengelolaan hutan Sesaot dapat mengakomodir kepentingan banyak pihak, teruatama bagi kesejahteraan masyarakat dan kelestarian hutan Sesaot.

\section{DISKUSI}

Dari uraian hasil dan temuan yang disampaikan di atas dapat dilihat bahwa yang menjadi sumber konflik pengelolaan SDA di hutan Sesaot adalah terancamnya akses dan hak pengelolaan masyarakat lokal atas SDA alam yang ada di hutan Sesaot setelah hutan Sesaot ditetapkan sebagai TAHURA. Dalam kacamata teori akses Ribot dan Peluso (2003) hilangnya akses terhadap SDA berarti hilangnya kemampuan untuk memperoleh manfaat dari SDA tersebut. Sementara itu, menurut Ostrom (2000) kehilangan akses terhadap SDA berarti hilangnya semua hak properti masyarakat lokal terhadap SDA yang ada hutan Sesaot. Kalau melihat Tabel 1, dengan hilanngya hak akses berarti hilangnya semua hak properti mulai dari hak: (i) mengalihkan hak, (ii) melarang, (iii) mengelola, (iv) memungut hasil, sampai (v) mengakses.

\begin{tabular}{|c|c|c|c|c|c|}
\hline \multirow[b]{2}{*}{$\begin{array}{c}\text { Kumpulat lak } \\
\text { (kunded of } \\
\text { rights) }\end{array}$} & \multicolumn{5}{|c|}{ Poss } \\
\hline & Penlik & Pengestan & Pengican & $\begin{array}{l}\text { Persoun } \\
\text { Rasni }\end{array}$ & Pengripg \\
\hline Nergaices & $x$ & $x$ & $x$ & $x$ & $x$ \\
\hline Ienodtail & $x$ & $x$ & $x$ & $x$ & \\
\hline Mengdotat & $x$ & $x$ & $x$ & $x$ & \\
\hline Nebay & $x$ & $x$ & & & \\
\hline 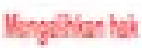 & $x$ & & & & \\
\hline
\end{tabular}

Tabel1. Kumpulan Hak Properti menurut Ostorm (2000) Sumber: Ostorm (2000) dalam Adiwibowo

Ancaman hilangnya akses dan hak pengelolaan terhadap SDA yang kemudian memicu konflik ini membenarkan teori pemicu konflik yang disampaikan Fisher (2001). Menurut Fisher, dihalanginya seseorang atau kelompok untuk memenuhi kebutuhannya atau tidak diakuinya keberadaan seseorang atau kelompok dalam kebijakan akan menjadi salah satu pemicu konflik. Situasi ini sebetulnya sudah digambarkan oleh Abraham Maslow (1943) dalam teori hirariki kebutuhan. Menurut Maslow, manusia akan memusatkan semua kemampuannya untuk memenuhi kebutuhan dasarnya dengan cara apapun. Manusia yang lapar akan melakukan berbagai cara untuk mendapatkan makanan walaupun harus mencuri atau melakukan aksi kejahatan yang anarkis.

Relasi, Kumpulan, dan Jaring-jaring Kekuasaan Lebih lanjutbilamenggunakan teoriakses Ribot dan Peluso 
(2003) dan teori dinamika akses, property, kekuasan, dan kewenangan Sikor dan Lund (2009) akan terlihat bahwa masalah akses dan properti mengenai SDA di hutan Sesaot berkaitan erat dengan kekuasan dan kewenangan yang dimiliki oleh pemangku kebijakan. Pemerintah Provinsi NTB yang dimotori Dinas Kehutanan Provinsi dengan kekuasaan dan kewenangan yang dimilikinya kemudian mengajukan perubahan status dan fungsi hutan lindung Sesaot menjadi TAHURA pada tahun 1998. Padahal, sebelumnya Pemerintan Provinsi NTB telah berhasil mengelola hutan Sesaot dengan melibatkan partisipasi masyarakat lokal dalam skema kerjasama penanaman kopi, sistem tumpang sari tanaman semusim, dan uji coba HKm. Dengan ketiga skema tersebut, meskipun tidak memiliki hutan Sesaot tetap diberi akses untuk mengelola dan mengambil manfaat untuk memenuhi keberlanjutan sistem livelihood-nya. Bagi Ditjen PHKA-Kementerian Kehutananyang menjadikan TAHURA sebagai program unggulannya, pengajuan TAHURA dari Pemerintah Provinsi NTB merupakan "berkah" bagi kekuasan dan kewenangannya yang memang mempunyai tupoksi dalam perlindungan hutan dan konservasi alam sehingga tak lama kemudian, yaitu pada tahun 1999, keluarlah SK Menteri Kehutanan Nomor 224/KPTS-II/1999 yang menetapkan hutan Sesaot sebagai TAHURA.

Pemerintah Kabupaten Lombok Barat yang merasa menjadi pemilik wilayah dari kawasan hutan Sesaot merasa dilangkahi dengan kebijakan ini terlebih adanya PP Nomor 62/1998 tentang penyerahan sebagian urusan pemerintahan di bidang kehtanan kepada daerah, termasuk hutan lindung Sesaot kepada Pemerintah Kabupaten Lombok Barat dan juga terbitnya SK Dirjen PHKA-Kementerian Kehutanan Nomor SK.579/ $\mathrm{DJ}-\mathrm{V} / \mathrm{KK} / 2001$ mengenai penyerahan pelimpahan kewenangan pengelolaan TAHURA Nuraksa Sesaot dari Pemerintah Provinsi NTB ke Pemerintah Kabupaten Lombok Barat. Selain itu, terancamnya livelihood akibat terancamnya akses dan hak kelola masyarakat lokal di sekitar hutan Sesaot yang merupakan penduduk Kabupaten Lombok Barat terhadap SDA di hutan Sesaot ikut mendorong Pemerintah Kabupaten Lombok Barat mengambil sikap untuk menentang kebijakan TAHURA yang diperjuangkan oleh Pemerintah Provinsi NTB.

Dalam uraian di bagian tahapan konflik SDA, terlihat bagaimana Pemerintah Provinsi NTB yang dimotori Dinas Kehutanan Provinsi dan Pemerintah Kabupaten Lombok Barat yang dimotori Dinas Kehutanan Kabupaten bersama masyarakat lokal yang diwakili KMPH saling berkontestasi dan berkonflik untuk memenangkan pertarungan atas kebijakan pengelolaan hutan Sesaot Dalam uraian tersebut dapat dilihat bagaimana kedua belah pihak membangun relasi (kumpulan dan jaringjaring) kekuasaan dengan mengandalkan kewenangannya sekaligus untuk mendapatkan tambahan kekuasan dan kewenangann. Yang menarik, kedua belah pihak berhasil menjalin relasi kekuasan dengan pihak Kementerian Kehutanan sehingga seringkali pada saat yang bersamaan keluar kebijakan yang berbeda dari Kementerian Kehutanan. Pemerintah Provinsi NTB yang mengusung TAHURA menjalin relasi kekuasan dan mendapat dukungan dari Ditjen PHKA-Kementerian Kehutanan, sedangkan Pemerintah Kabupaten Lombok Barat dan KMPH yang menngusung HKm menjalin relasi kekuasan dan mendapat dukungan dari Ditjen RLPS-Kementerian Kehutanan. Relasi kekuasaan yang dibangun ini kemudian membangun jaring kekuasaan yang sama kuat. Terbukti dari keluarnya SK Menteri Kehutanan, yaitu (i) SK Menteri Kehutanan Nomor 445/Menhut/2009 tentang Penetapan Areal Kerja HKm seluas $185 \mathrm{Ha}$ di Kabupaten Lombok Barat dan (ii) SK Menteri Kehutanan Nomor 598/Menhut-II/2009 yang memantapkan perubahan status hutan lindung Sesaot menjadi TAHURA, yang bertentangan pada tahun yang sama.

Karena jaring kekuasaan yang sama kuat inilah, konflik pengelolaan SDAdi hutan Sesaot ini tidak bisa diselesaikan lebih dari 10 tahun. KONSEPSI yang memang sejak tahun 1995 ikut membina masyarakat lokal sekitar hutan Sesaot akhirnya ikut turun rembug dengan menggalang jaringan kekuasaan baru melalui menjalin kemitraan dengan Ford Foundation, ACCES Phase II, LEI, ICRAF, FKKM, ICEL, FFI, Dewan Kehutanan Nasional, World Neighbors dan Lapera menyelenggarakan Sangkep Beleqyang mempertemukan Kelompok Pendukung TAHURA dan Kelompok Pendukung HKm pada tanggal 28-29 Desember 2010. Pada kesempatan itu, hadir juga Staf Ahli Menteri Kehutanan, Prof Dr San Afri Awang, M.SC; Staf Ahli Menteri Koperasi, Ali Herman Ibrahim; dan Ketua Dewan Kehutanan Nasional, Prof Dr Agus Setiarso di tengah ribuan masyarakat sekita hutan Sesaot. Sangkep Beleqyang kemudian dilanjutkan dengan pertemuan konsolidasi lanjutan di Gedung Manggala Wanabakti, Jakarta pada 24 Januari 2011 akhirnya merekomendasikan diteruskannnya program HKm dan dipindahkannya TAHURA ke Sumbawa.



Gambar4.KonflikPengelolaanSDAdiHutanSesaotdan Jaring-jaring Kekuasaan Aktor-aktor yang Terlibat 
Konsolidasi lanjutan kemudian dilakukan pemerintah melalui Kementerian Kehutanan pada 24 Januari 2011 di Gedung Manggala Wanabakti, Jakarta. Hasilnya, HKm pun direkomendasikan diteruskan dan TAHURA direkomendasikan dipindah ke Sumbawa. Di selasela Rapat Kerja Bappeda se-NTB, Kepala Bappeda NTB mengatakan bahwa Pemerintah Provinsi NTB akan melaksanakan kesepakatan dan rekomendasi yang dihasilkan Sangkep Beleq 28 Desember 2010 dan konsolidasi lanjutan 24 Januari 2011 di Gedung Manggala Wanabakti, Kementerian Kehutanan, Jakarta. Menindalanjuti hasil ini, Pemerintah Provinsi NTB secara resmi pada 29 Januari 2011 mengumumkan akan mengusulkan kembali hutan Sesaot menjadi hutan lindung dengan model HKm dan memindahkan lokasi TAHURA Provinsi NTB ke wilayah lain. Gambaran relasi, kumpulan, dan jaring-jaring kekuasaan dalam konflik pengelolaan SDA di hutan Sesaot dapat dilihat pada Gambar 4

\section{PENUTUP}

\section{Skema HKm Kolaboratif sebagai Jalan Keluar}

Dari uraian temuan yang dilanjutkan dengan diskusi dapat dilihat bahwa konflik pengelolaan SDA di hutan Sesaot yang bersumber dari perebutan akses dan hak pengelolaan SDA yang terjadi di antara Pemerintah Provinsi NTB sebagai pihak yang merasa punya kekuasaan dan kewenangan dalam mengelola hutan Sesaot dengan masyarakat lokal sebagai pihak yang memanfaatkan SDA hutan sesaot yang kemudian mendapat dukungan dari Pemerintah Kabupaten Lombok Barat sebagai pihak yang juga merasa kekuasaan dan kewenangan dalam mengelola hutan Sesaot. Meskipun sesekali konflik disalurkan melalui unjuk kekuatan fisik, yaitu unjuk rasa oleh masyarakat (KMPH), namun sebagian besar konflik disalurkan lewat perang gagasan dan kebijakan. Dengan realasi, kumpulan, dan jaring kekuasaan yang dimilikinya pihak yang mendukung TAHURA berkali-berkali mengeluarkan kebijakan yang melegitimasi TAHURA sebagai bentuk pengelolaan SDA hutan Sesaot. Begitu pun sebaliknya dengan pihak yang mendukung $\mathrm{HKm}$. Uraian pada tahapan konflik menunjukkan kedua belah pihak sama-sama kuat dan tidak mau mengalah sebelumnya datang inisiasi dari pihak ketiga yang berhasil meredakan konflik dengan keputusan akhir mengembalikan status fungsi hutan Sesaot dengan skema HKm dan memindahkan lokasi TAHURA ke wilayah lain di luar kawasan hutan Sesaot.

Pertanyaan selanjutnya adalah apakah keputusan ini merupakan keputusan akhir yang bisa bertahan dan berjalan dengan baik selamanya? Bukankah Fisher (2001) menyatakan bahwa fase akhir: pasca-konflik bisa berubah menjadi fase awal: pra-konflik ketika isu-isu yang menjadi pemicu kembali mencuat? Oleh karena itu, penulis mencoba menawarkan solusi sebagai jalan keluar. Penulis menyarankan ada modifikasi dari skema $\mathrm{HKm}$ yang selama ini dilakukan. Kedepan, skema HKm hendaknya dilakukan dengan pendekatan kolaboratif manajemen sehingga mampu menampung kepentingan semua pihak, baik Pemerintah Pusat, Pemerintah Provinsi, Pemerintah Kabupaten, masyarakat, dan pengambil manfaat lainnya dari SDA hutan Sesaot. Apalagi, jika menggunakan teori pengelolaan sumberdaya alam Birner dan Wittmer dalam Satria (2012), solusi ini merupakan solusi yang paling tepat (Gambar 5). Seperti yang diuraikan dalam temuan maupun diskusi terlihat kapasitas pemerintah, baik Provinsi maupun Kabupaten, dan juha modal sosial masyarakat lokal sama-sama kuat.
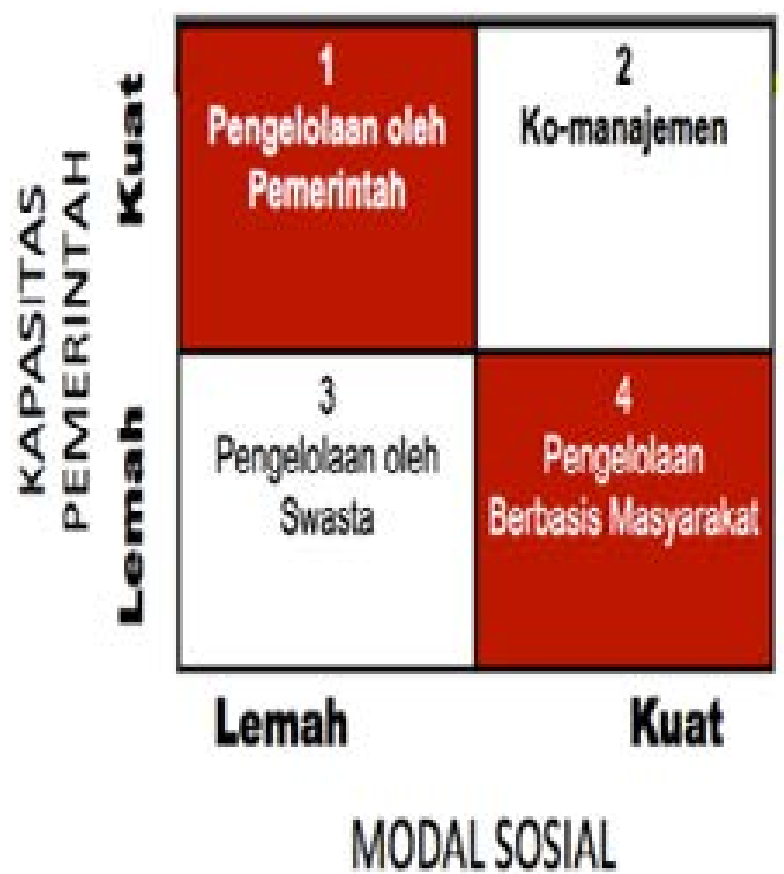

$\begin{array}{llccc}\begin{array}{l}\text { Gambar } \\ \text { Pengelolaan }\end{array} & \begin{array}{c}\text { Matriks } \\ \text { Sumberdaya }\end{array} & \begin{array}{r}\text { Podel } \\ \text { Alam }\end{array} \\ \text { Sumber : Birner dan } & \text { Wittmer dalam Satria } & (2012)\end{array}$

Untuk menjamin pelaksanaan pengelolaan SDA hutan Sesaot dengan skema HKm Kolaboratif berjalan dengan baik sesuai harapan semua pihak perlu dipenuhi syaratsyarat yang diajukan Pomeroy dan Williams (1994) sebagai berikut: (i) batas-batas wilayah yang terdefinisi, (ii) kejelasan status sosial masyarakat (kenggotaannya), (iii) ketergantungan terhadap sumberday alam, (iv) memberikan manfaat, (v) pengelolaan yang sederhana dan mudah diimplementasikan, (vi) legalisasi dari sistem pengelolaan, (vii) kerjasma pimpinan formal dan informal, (viii) desentralisasi dan pendelagasian wewenang, (ix) koordinasi, sinkronisasi, dan interaksi antar stakeholder, dan (x) keterpaduan pengelolaan sumberdaya oleh para stakeholders.

\section{DAFTAR PUSTAKA}

Adiwibowo, Soeryo dan Rina Mardiana. 2009. Pengelolaan Kolaboratif Hutan Produksi Berbasis Masyarakat: Kasus Pengelolaan Hutan Negara di Wonosobo, Jawa Tengah. Dalam Social Forestry di Indonesia: Kolaborasi Pengelolaan Sumberdaya Hutan. Ditjen Rehabilitasi Lahan dan Perhutanan Sosial, Departemen Kehutanan.

Adiwibowo, Soeryo. 2013. Akses dan Hak Atas Properti/ Sumberdaya Alam (Property Right). Bahan Mata Kuliah Ekologi Politik. Program Studi Sosiologi Pedesaan, SPs-IPB, Bogor.

Adiwibowo, Soeryo. 2013.. Access and Property: 
A Question of Power and AuthorityThomas Sikor \& Christian Lund. Bahan Mata Kuliah PSBM. Program Studi Sosiologi Pedesaan, SPs-IPB, Bogor

Aji, Gutomo Bayu, Joko Suryanto, Rusida Yulianti, Amorisa Wiratri, Temi Indriati Miranda, dan Ali Yansyah Abdurrahim. 2011. Model Pengurangan Kemiskinan di Desa-desa Sekitar Hutan: Pengembangan Social Forestry di Jawa Barat dan Lampung. Makalah Rekomendasi Kebijakan. Program Penelitian Kompetitif-Sub Program Critical and Strategic Social Issues LIPI, Jakarta.

Galudra, Galma, Yana Buana, Noviana Khususiyah. 2010. Mau Melangkah ke Mana Pengelolaan Hutan Sesaot? Brief Nomor 9-Policy Analysis. World Agroforestry Centre, ICRAF Southeast Asia Regional Office dan Ford Foundation.

Kuswijayanti, Elisabet Repelita, Arya Hadi Dharmawan, dan Hariadi Kartodihardjo. 2007. Krisis-Krisis Socio-Politico-Ecology di Kawasan Konservasi: Studi Ekologi Politik di Taman Nasional Gunung Merapi. Sodality: Jurnal Sosiologi Pedesaan Vol 01 No 01, April 2007, hlm 41-66.

Klock, John. 2008. Historic Hydrolic Landscape Modification and Human Adaptation Lombok, Indonesia from 1894 to the Present. Geo 522.

Ostrom, Elinor. 1990. Governing the Commons: The Evoltion for Collective Action. Cambridge University Press.

Pomeroy, RS dan MJ Williams. 1994. Fisheries CoManahement and Small Scale Fisheries: A Policy Brief. ICLARM. Manila.

Ribot, Jesse C. \& Nancy Lee Peluso. 2003. A Theorr of Access. Rural Sociology 68(2) pp 153-181.

Satria, Arif. 2012. Perikanan Internasional. Bahan Mata Kuliah Ekologi Politik. Program Studi Sosiologi Pedesaan, SPs-IPB, Bogor.

SCBFWM. 2010. Peoyek Penguatan Pengelolaan Hutan dan DAS berbasis Masyarakat. Buleten SCBWFM Nomor 1, September 2010. Kemenhut, UNDP, dan GEF.

Sikor, Thomas \& Christian Lund. 2009. Access and Property: A Question of Power and Authority. Development and Change 40(1): 1-22.

Warman, Kurnia, Idris Sardi, Andiko, Gamam Galudra. 2012. Studi Kebijakan Penguatan Tenurial Masyarakat dalam Penguasaan Hutan. WAF, Huma, dan Packard Foundation.

Zainuddin, Sulthan, Endriatmo Soetarto, Soeryo Adiwibowo, dan Nurmala K. Pandjaitan. 2012. Kontestasi dan Konflik Memperebutkan Emas di Poboya. Sodality: Jurnal Sosiologi 